\title{
Synergetic basis of author's educational cognitive dictionaries
}

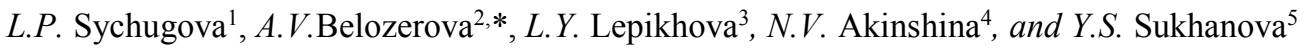 \\ ${ }^{1}$ Vyatka State University, 36, Moskovskaya st., 610000, Kirov, Russia \\ 2, 3, 4, 5 Don State Technical University, 1, Gagarin sq., 344000, Rostov-on-Don, Russia
}

\begin{abstract}
The authors analyzed techniques of formation of a conceptual system on the synergistic basis of language and speech learning using authors' cognitive dictionaries. Synergetic dictionaries are created taking into account: 1) student's perception of randomly perceived facts; 2) consolidation and bifurcation in the minds of cumulative images of the world by verbal and non-verbal means; 3) systematization, streamlining of information obtained through mental actions. The authors conclude that cognitive information verbalized in dictionaries is represented by syntagmas; predicates are a basis of sentence structures; the object prediction is one of the most important stages of the mechanism of translating internal speech into external one. Expansion of the entire cognitive base, including extralinguistic and linguistic components, contributes to mental activities of the speaker.
\end{abstract}

\section{Introduction}

The 21 st century imposes more complex requirements on teaching methods: the main task is not only the search for new approaches and teaching methods, but formation of a personality of future teachers capable of selflearning, self-improvement and self-development. This is possible if the teacher goes beyond the "classical linear view of linguistic education and expands his methodological boundaries by developing a new view of hierarchical layers of linguistic knowledge" [1] a synergistic view.

\section{Problem Statement}

A synergistic approach to training of future language teachers in general and language learning in particular is aimed at "studying language and speech phenomena and processes based on the principles of selforganization and self-regulation of the language system and reflecting cultural and historical phenomena" [1]. The synergistic approach will form a lingo-synergetic thinking, enhancing speech and thinking activities if learners.

The method of working with cognitive dictionaries can be implemented through a model of learning the language as a complex self-developing system which forms an understanding of the holistic language picture of the world.

The purpose of the article is to present a synergistic basis for training future language teachers and ways to enhance student's cognitive activities using Cognitive dictionaries.

A synergetic, interdisciplinary direction was analyzed from the point of view of "philosophical- semiotic-synergetic interpretation of linguistic processes" [2].

\section{Main Part}

Let us present a conceptual and terminological apparatus that will be used in the work. The concept is based on two sciences: 1) synergetics is a science of unity, isomorphism of natural laws and laws of development of living organisms, self-organization of physical, biological and social systems. The modern dictionary of foreign words describes synergetic (gr. Synergetikos joint, consistently acting) as a science that considers nature, the world as a self-organizing complex system [3]; 2) cognitive linguistics exploring concepts as a mechanism for presenting knowledge through language. According to V.K. Radzikhovskaya, cognitive linguistics is not only an applied science. It is a fundamental science which reveals general laws of movement of complex systems - laws of synergetics" [4, 5].

According to S.G. Gural, a synergistic analysis of language makes it possible "to obtain new knowledge about meaning formation, organization of communicative processes, methods of teaching languages" [6]. "Synergetics explains how cognitive (including linguistic) processes and the environment interact in the space-time continuum" [7].

Despite the fact that synergistic patterns were discovered and described by G. Haken in the framework of natural sciences, in particular physics, synergetic concepts were transferred to linguistics and are used to explain linguistic processes. At the end of the 20th century - the beginning of the 21 st, a new direction developed in the humanitarian field

\footnotetext{
* Corresponding author: belochka-04.80@mail.ru,
} 
of knowledge - linguosynergetics. According to A.G. Antipov, "synergetic linguistics" deals with a task of learning language in terms of its dynamic properties. It reveals an invariant nature of language, shows structural parameters of its development and their functional relevance. The scientist concludes that "the synergistic highlights universal principles of development

of the language structure [8].

A synergistic approach to language has been developed by foreign and Russian scientists (N. Chomsky, U. Maturana, N.F. Alefirenko, N.L. Myshkina, V.N. Bazylev, R.G. Piotrovsky, L.V. Bronnik, S.A. Lamzin, T.Yu. Tambovkina, S.K. Gural, O.M. Voskerchyan, LD Babakova, L.B. Olekhnovich).

In the methodology of teaching Russian as a native language, the synergistic approach was described by O.V. Alekseeva and L.P. Sychugovoy [9, 10]. In our opinion, this is due to the fact that synergisticallyminded linguistic-cognitive scientists face methodological

and axiological difficulties. According to L.V. Bronnik, "linguistics focuses on unambiguity, verifiability of scientific knowledge, opposition of induction and deduction, empiricism and theory, etc. Meanwhile, in post-non-classical studies, a new general scientific type of thinking has been established. Evolutionary synergistic knowledge is synthetic knowledge, interpretive in nature, dependent on the cognitive context. This specifics requires other standards of scientific

and other ways of obtaining it" [11].

knowledge,

The method described in the article, value orientations of cognitive-synergetic cognition, methods used

for forming a conceptual system on the synergistic basis of language and speech teaching using Cognitive dictionaries are relevant.

In our opinion, bifurcation is a key component of the synergistic approach to the method of language teaching. Bifurcation (Latin bifurcation - branching) is a state of the system in which its further development is possible: a struggle of two fronts in the atmosphere changing weather; a state of choice; a branching point of a family tree; a point of transition to a new form of communication. The bifurcation point can be positive (insight, discovery) or negative. A visual illustration of the bifurcation point is a picture by V.M. Vasnetsov "The Knight at the Crossroads" or a statement from N.V. Gogol's work "The auditor is going to us." The point of bifurcation, according to S.K. Gural, is the intersection of speech fields, "where the generation of meanings, new discursive stages" occurs [1].

Let us present the principles of pedagogical synergetics used when working with Cognitive dictionaries. reality.

The principle of relationship of language signs and

Studying the living word in the informationdiscursive environment.

Taking into account achievements of psycholinguistic science: identification of features of the structure and work of the brain (ensuring the unity of left and right hemisphere, figurative thinking; accounting for the stages of speech imitation and speech perception). (see N.I. Zhinkina, A.R. Luria, etc.).

The principle of conceptualization. Introduction of figurative components (photos, drawings, etc.) in the Cognitive dictionary entry.

The principle of accounting for achievements of cognitive linguistics and implementation of a cognitive-communicative approach to speech activities of future linguists (assimilation of the terms "concept", "notion").

The principle of reliance on the system. The system (Greek sýstēma - a whole made up of parts, relation) is one of the categories of synergetics; "A set of elements that are in relationship with each other, forming unity" [3]. The idea developed by Yu.N. Karaulov about the language system of native speakers in three subsystems (verbal-semantic, linguistic-cognitive, and communicative) has become significant in linguistics and language teaching. On the basis of the quantumsynergetic theory, V.K. Radzikhovskaya developed a system of human interaction with the world and other people referring to it as a functional-semantic category of reciprocity $[4,5]$.

The unity of the public education system and the system of training and education taking into account individual practices: the observance of purposes of the Federal State Educational Standard, implementation of the program as an indestructible system of education, self-development, a search for innovative methodical ways.

In the system of language teaching language methods, the following categories were distinguished: a language system; a system of methods based on the laws of language and speech learning; a system of the subject of language learning [12]. Modern scholars added a system of culture, a system of preserving traditions and continuity of generations, a system of perspective education.

In the author's educational Cognitive dictionaries [13, 14], categorization, conceptualization, and verbalization are presented as a single synergetic process.

The method (French method, Greek Methodos a path of research). Synergistic capacity of the term can be observed in the definition given by L.A. Khodyakova: "The method is a tactical model of the learning process reflecting a set of interrelated actions of a teacher and students aimed at achieving goals of education" [15]. Thedefinition meets synergistic requirements. The system method is represented as a system open to the interconnection of internal components capable of interaction; a non-equilibrium system ready to accept new components.

The principle of development of the ability to work with chaos. The principle of self-organization. Selforganization is a spontaneous transition of an open system from less complex to more complex forms. In self-organizing systems, evolution proceeds from chaos to order and vice versa. Chaos is "an infinite space, a disorderly mixture of material elements of the 
world" [3]. Let us organize examples of functions of the terms from the cards containing observations of its use in speech (see the structure of a dictionary entry).

We believe that Cognitive Dictionaries are an effective means of shaping thinking, translating internal speech into external one. Let us describe synergistic features of dictionary entries $[13,14]$.

Elimination of apparent contradictions between the language system and the speech system on the basis of the distinction of concepts of language and speech. Language is a means of communication. Speech is a human activity. "There is a word as an analogue of the object of reality and as a unit of language included in the communicative process. It is necessary to distinguish signs of the language system which are means of knowledge, and signs of the speech system which are means of communication" [16]. The basis of dictionaries are language units in the language and speech systems. The cognitive information verbalized in the Dictionaries is presented by lexeme blocks, syntagmas. Examples of self-organization of nonequilibrium systems are as follows: 1) the linguistic system of signs: words, phrases, sentences, texts (a system which is closed to new types of signs) and 2) the speech system which is open, correlated with reality. Dictionary entries present concepts reflecting relationships of of the world and the linguistic picture of the world; the dictionary is a tool for organizing cognitive, communicative activities.

Preserving the integrity of thinking. The dictionaries take into account processes of processing and storing knowledge, extracting and organizing language units for transferring information to other persons. Since the prediction of an object of thought is one of the most important stages of the mechanism for translating internal speech into external one, Cognitive dictionaries provide predicates - a basis for structuring a sentence.

Let us consider the composition of dictionary entries. Each one consists of four parts: a heading, combinations, examples, and references. The heading includes: 1) a word; 2) orthoepic markers (stress, pronunciation); 3) grammatical markers; 4) interpretation. Each meaning develops independently in the dictionary entry. The combination part reveals the relationship of the heading word with other words of the Russian lexical system. Let us describe the compatibility of the noun. The noun is described in the order of cases: noun phrases (without prepositions; with prepositions in an alphabetical order), verb phrases (without prepositions; with prepositions in an alphabetical order), predicative combinations (subject + predicate). Examples show the use of the word in speech. Scientific texts

on visual arts were widely used as illustrative materials. The fourth part of the dictionary entry - references explains meanings of words that do not have their own entries. Information about etymology, word formation is given in the reference part.

Let us give an example of an entry of the Cognitive dictionary of the Russian language.
БАРАБА 'Н, -а; бараба'ны, -ов; м. Венчающая часть здания; ичилндрическая или многогранная стена, несущая купол .

По архитектурному объёму: циилиндрический...;

по плану: восьмигранный, гранёньй, кругльиц...;

по перекрытию: купольньй...;

по конструкции: глухой...;

по назначению: световой...;

по месту расположения: подкупольный, иентральный...;

по размеру: высокий, узкий...;

по образности художественной речи: лёгкий, стройный... барабан.

Какой-л. барабан какого-л. (-ой) здания: собора, храма...; части здания: главы, купола...

Какой-л. барабан с каким-л. антаблементом, кольцьм каких-л. колонн, куполом...

Какие-л. (-ое, -ая) окна, основание, отделка, роспись...; высота...; размещение, расположение... какого-л. барабана.

Какой-л. уступ... между какими-л. барабаном и куполом.

Какие-л. (-ой) окна, купол... на каком-л. барабане.

Поддерживать...; завершить (каким-л. аттиком...), сложить (из каких-л. кирпичей...), увенчать (каким-л. куполом...), украсить (какими-л. кокошниками...)... какой-л. барабан.

Завершить (какую-л. колокольню...)... какимл. барабаном.

Какие-л. простенки (между какими-л. окнами)... внутри какого-л. барабана.

Поддерживать (какой-л. купол...), увенчать (какой-л. фасад....)... каким-л. барабаном.

Опираться...; поднять (какой-л. купол...)... на какой-л. барабан.

Покоиться...; сосредоточить (какие-л. узоры...)... на каком-л. барабане.

Подвести (какое-л. здание...)... под какой-л. барабан. купола);

Барабан служит (основанием какого-л.

служит опорой (купольному перекрытию)...; (обычно...) прорезан (окнами);

распространён (в христианском

зодчестве)...;

(венчающая...) часть здания...

Какой-л. барабан возвышается;

держится (на каких-л. столбах...);

завершает (какое-л. здание...);

имеет (какой-л. диаметр; какую-л. особенность; многогранную, изилиндрическую... форму...);

находится (над каким-л. восьмериком...);

несёт на себе (какой-л. купол...);

опирается (на какие-л. столбы...);

стоит (на каком-л. постаменте...)...;

выложен (из кирпича...);

завершён (каким-л. аттиком...);

окружён (какими-л. колоннами...); 


\section{поставлен;}

прорезан (какими-л. окнами);

увенчан (каким-л. куполом);

украшен (какими-л. арочками, кокочниками, декоративным мотивом...)...

* Успенский собор Киево-Печерской лавры в Киеве. 1073-1089.

Он был построен князем Святославом Ярославичем и представлял собой обширный $и$ высокий трёхнефный храм, увенчанный единственным куполом. Мощзные и строгие пилоны членили внутреннее пространство. Свет из барабана и стенных окон равномерно освещал центральный куб здания. (History of Russian and Soviet Arts. Moscow, 1989. P. 16).

Светово'й барабан - барабан с окнами.

Ше'йка (ще'я) - глухой барабан, несущий церковную главку; барабан, не имеющий окон.

Let us describe the methods used when working with cognitive dictionaries.

At first glance, we perceive a verbal chaos when selecting required means as an ordered system of language units and a self-organizing speech system of units selected by the reader to express his thoughts.

Analysis of texts as part of contexts. Analysis of vocabulary articles, tables aimed at identifying relationships of objects and phenomena existing in the world.

Observations on how the nature of a perceived subject / phenomenon manifests itself on the basis of predicates, reveals the interaction of individual elements of language and speech, inseparability of language and speech systems.

Bringing evidence to support the unification of functions of the word as a unit of language and the word as a unit of speech.

Development of techniques for working with a dictionary entry containing tables.

Compilation of the model dictionary entry corresponding to a topic of the lesson.

The method of a dialogue with the world and life. Let us give examples of stimulating the tasks.

- How does the Cognitive Dictionary differ from famous explanatory dictionaries?

- What are the grammatical connections of the word as a semantic unit with units of other language levels?

- Analysis of interpretations.

- What is the concept of linguistic personality? What is the role of the concept in educational practice?

- What is the revaluation of the lexical semantic meaning of the word chaos in the light of the theory of synergetics? Why do concepts of chaos and order (chaos and Beauty, chaos and Cosmos) appear in the synergetic theory as inseparable from each other?

- How do objects, phenomena of the world of art manifest themselves in qualities, properties, connections with the world of other objects and phenomena, relations with a person who uses the term?

- Explain the synergy of the term thought-speechlanguage action $[4,5]$. Why does the linguist develop the concept of trinity of thought-speech-language as a quantum synergetic concept?
- Why the concepts thought, speech, language should not be studied in isolation from each other? Can a modern methodical system be considered synergetic?

- Do we understand the phrase "In the beginning was the word ..."? (The word has an expanded meaning. The word is the Beginning, Deed, Order, Cosmos. The Bible says: "... And the word was a deed, and God did it.") In Cognitive dictionaries, the word is a concept.

- Do you agree that the word as a cognitivesynergistic phenomenon is an image of discursive interaction of subject and object? [17]. Justify the answer.

- P.A. Florensky said that "the word is synergistic < $\ldots>$ The word is bigger than itself. Moreover, it is a subject of knowledge and an object of knowledge" [18]. Expand the philosopher's thought to a full-fledged reasoned statement.

- Give examples of bifurcation in art, i.e. such works that represent a state of the system in its further movement, development, transformation.

- Remember your state of creative inspiration. Do you agree that every creature is a cosmos mixed with chaos? Justify your opinion.

- How do the Cognitive dictionaries show how each language unit lives in its own system / subsystem, interacts with other language units?

- How is the role of the word (how do language units interact, how does a person understands the world) in keeping a genetic code, developing abilities is shown?

- What methods of work with the dictionary entry are used in schools?

- Can be the use of Cognitive Dictionaries for writing an essay called a bifurcation?

- Tell about the bifurcation using the example of development of methodical science.

- What was the beginning of bifurcation for endless documentation work in modern education?

- How do "parcelations violate literary norms" [19], becoming a vivid example of the bifurcation?

- How does our native language teach us be aware of our nationality?

"The whole is not the sum of the parts." What does it mean?

- What are the ways to implement a synergistic / holistic approach to speech formation?

- Can our discussion be considered synergistic communication?

- Is it necessary to introduce initial theoretical synergy information in the lecture "Methods of teaching Russian language"?

\section{Conclusion}

We presented a methodology for enhancing students' speech and thinking activities based on cognitive synergistic dictionaries. The theoretical and methodological strategy presented in the Dictionaries is used in the light of synergetics. It helps understand a single isomorphic process, i.e. the interaction of all human life systems with the nature and space. 


\section{References}

1. S.K. Gural, Bulletin of the Pedagogical University of Culture and Science, Discourse analysis in the light of synergistic vision, 6, 13-17. (2012)

2. I.V Sergeyev, N.S. Olizko, Bulletin of NSTU, Text, hypertext and intertext in the works ин J. Morrison 430. 33-38., (2018)

3. A.N. Bulyko, Over 25 thousand words and phrases, Modern dictionary of foreign words. 848, (Martin, 2005)

4. V.K. Radzikhovskaya, Functional-semantic category of reciprocity in modern Russian: a quantum synergistic aspect. (Prometheus, 2005)

5. V.K. Radzikhovskaya Strategies for the development of methods of teaching Russian language in the context of modern educational standards, On synergy of language studies, 512 (FORUM, 2005)

6. S.K. Gural, Bulletin of NITU, Synergetic and Lingvosynergetics, 302, 7-9. (2007)

7. O.M Voskerchyan., L.D. Babakova., B.N. Morenko., E.I. Kotova, Sociocultural and philological aspects in the educational and scientific context. First International Forum in Japan on Russian Studies, Culture, Pedagogy, Lingvosynergetics in the methodology of teaching Russian as a foreign language, 152-154. (Tanaka Print, 2014)

8. A.G. Antipov, Siberian Journal of Philology, Synergetic Linguistic Form (to clarify the concept of "natural phonology"), 3, 145-158, (2003)

9. O.V. Alekseeva Problems of studying a living Russian word at the turn of the millennia: materials of the Intern. scientific Conf., October, Formation of experience with bachelors: a synergistic approach in the practice of teaching methods of the Russian language, 28-29, 274-278. (Voronezh, 2017)

10. L.P. Sychugova Problems of studying a living Russian word at the turn of the millennium: materials of the Intern. scientific Conf., October Studying words as units of language and speech in the light of linguistic-cognitive and synergetic approaches 2829, 332-337, (Voronezh, 2017)

11. L.V. Bronnik A cognitive-synergistic approach to language: philosophical and methodological analysis (2013).

12. A.P. Eremeeva, Implementation of modern approaches to teaching Russian language taking into account traditions of the national methodology: To the 190th anniversary of the birth of F.I. Buslaeva: materials scientific practical conf. March 20-21, Fundamental categories of methodology and their implementation in the innovative development of teaching Russian language, 2008, (MPGU: REMDER, 2008.)

13. L.P. Sychugova Dictionary of Arts. 452, (VSU, 2008).

14. L.P. Sychugova Cognitive dictionary of architecture. 293, (OOO Raduga-PRESS, 2012)

15. L.A. Khodyakova, Polyphony of methodical approaches to teaching Russian: materials of International scientific and practical conf. March, Polyphony of methodological approaches in the preparation of the future teacher of Russian as a foreign language 15-16, 2012, 452, (MPGU: REMDER, 2012)

16. A.L. Charandin, Questions of cognitive linguistics, The dynamic nature of conceptualization and categorization as the basis of human speech activity, 1, 75-81, (2013)

17. N.F. Alefirenko, Philology and Culture. Philology and Culture, Event Synergetics of Text Implicitness in Linguopoetic Illumination, 1 (23), 114-119. (2011)

18. 18. P.A. Florensky Pillar and statement of truth: 2, 447 (M., 1990)

19. O. V. Nikolenko, Parcelled phrases in the aspect of business communication, IOP Conference Series: Materials Science and Engineering, 483. Retrieved from:

https://iopscience.iop.org/artticle/10.1088/1757899X/483/1/012106/pdf, (2019) 